\title{
Challenges in Administration of Corticosteroids for the Treatment of Addison's Disease: A Case Study of Fludrocortisone Acetate
}

\section{Najim A AL-Awwadi ${ }^{1 *}$ and Makarim M. Ali Hassan ${ }^{2}$}

${ }^{1}$ Faculty of pharmacy, Chair man of department of pharmacognosy, University of Thi-Qar, Iraq

${ }^{2}$ Faculty of pharmacy, Department of basic science, University of Thi-Qar, Iraq

\begin{abstract}
Fludrocortisone is a known corticosteroid used to control the amount of sodium and fluids in body. Fludrocortisone act by decreasing the amount of sodium that is excreted in your urine. It is indicated to take orally and it is recommended not to stop Fludrocortisone treatment without Physician consent as sudden stoppage leads to several moderate to severe adverse effects.

There are several moderate to severe adverse effects reported with treatment of Fludrocortisone including high Blood Pressure (BP), Heart failure, weakness of muscles, changes in mood and low immune system function. Considering this there is need to develop sustained release formulation as microparticles which help to improve patient compliance by reducing dosage frequency which overall help to reduce side effects reported with Fludrocortisone.

The aim of this research is to develop different formulations of Fludrocortisone (FLU) by using various polymers (poly( $\varepsilon$-caprolactone, PLC), Eudragit ${ }^{\circledR}$ RS and Eudragit $\left.{ }^{\circledR} R L\right)$ and different processes (oil-in-water $(\mathrm{O} / \mathrm{W})$ solvent evaporation methods and suspension-in-oil-in-water (S/O/W) evaporation methods). Small poly( $\varepsilon$-caprolactone (PCL)-based microparticles have successfully developed during study which was leading to good efficiency when it was prepared by oil-in-water $(\mathrm{O} / \mathrm{W})$ emulsion method with $7.5 \mathrm{mg} / \mathrm{ml}$ of FLU.
\end{abstract}

Keywords: Fludrocortisone; Microparticles; Polymer; Sustained release; Poly(ع-caprolactone)

\section{Introduction}

In Addison's disease, adrenal gland doesn't produce enough hormones. It is categorized as either primary or secondary. In secondary adrenal insufficiency, adrenal gland is not stimulated by pituitary gland and there is lack of production of hormone cortisol.

It is categorized as autoimmune disorder as body's own immune system is affected and it's destroyed over period of time (Figure 1) [1-4].

\section{Symptoms of Addison's disease}

Most of the symptoms develops gradually in this case, it develop to severe stage at the time of progression.

- Weakness of muscle.

- Irritation.

- $\quad$ Salt carving.

- Pigmentation.

- $\quad$ Disorder like depression, Anxiety.

- Disturbance in menstrual period.

- Chronic fatigue.

It is very difficult to diagnose this disease due to similarity of symptoms with others, however hyperpigmentation is marker to diagnose this disease. Biochemical test is key for the diagnosis along with X-Ray of adrenal and pituitary gland (Figure 2) [4-9].

If symptoms worsening, this leads to Adrenal Crisis which needs immediate medical attention. The common symptoms are as under:

- Excessive vomiting.

- Dehydration.

- $\quad$ Abdomen, back and leg pain.
- $\quad$ Sudden, severe pain in the lower back, abdomen, or legs.

- $\quad$ Severe vomiting.

- $\quad$ Severe diarrhoea.

- Dehydration.

- $\quad$ Low blood pressure.

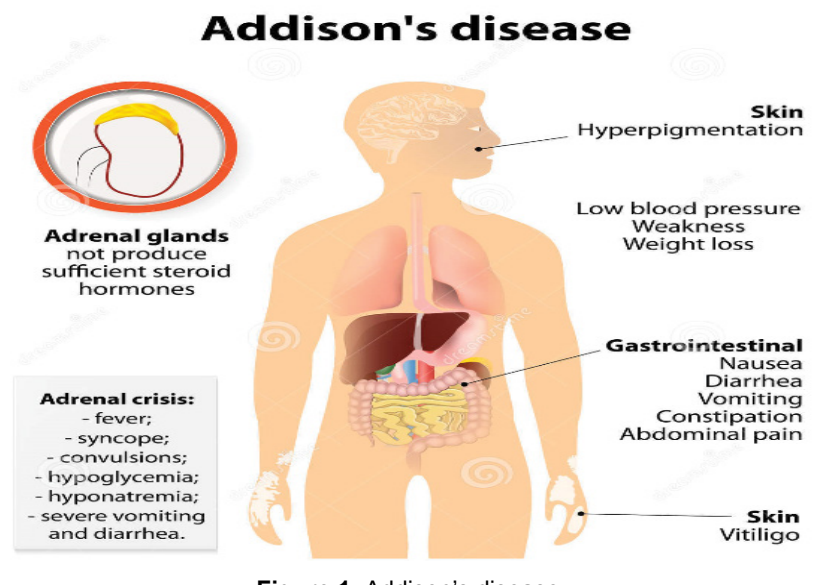

Figure 1: Addison's disease.

*Corresponding author: Najim A AL-Awwadi, Faculty of pharmacy, Chair man of department of pharmacognosy, University of Thi-Qar, Iraq, Tel: 00964 7810877994; E-mail: najimabbas@yahoo.fr

Received May 23, 2017; Accepted June 21, 2017; Published June 28, 2017

Citation: AL-Awwadi NA, Ali Hassan MM (2017) Challenges in Administration of Corticosteroids for the Treatment of Addison's Disease: A Case Study of Fludrocortisone Acetate. J Bioanal Biomed 9: 164-168. doi:10.4172/1948593X.1000172

Copyright: (c) 2017 AL-Awwadi NA, et al. This is an open-access article distributed under the terms of the Creative Commons Attribution License, which permits unrestricted use, distribution, and reproduction in any medium, provided the original author and source are credited. 
- Loss of consciousness.

If this condition is not treated on time, this will leads to death. It is treated with adrenal hormones and an IV hormone is ideal in this case.

Some of the hormones produced by the cortex are important for life; they are the glucocorticoids and the mineralocorticoids.

- Glucocorticoids. It is hormone, which influence key role in immune system and help to convert food in to energy which help to respond during stress condition.

- Mineralocorticoids. It is important to maintain sodium and potassium balance in body. It is useful for BP maintenance.

- Androgens. These are sex hormones which influence muscle mass, libido and sense of wellbeing in male and female.

Corticosteroids (Fludrocortisone) are patented medicine and it is included in essential medicine by the World Health Organization's list of Essential Medicines. In this study, different microparticles were

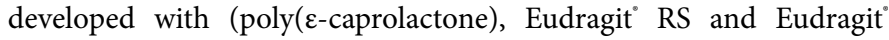

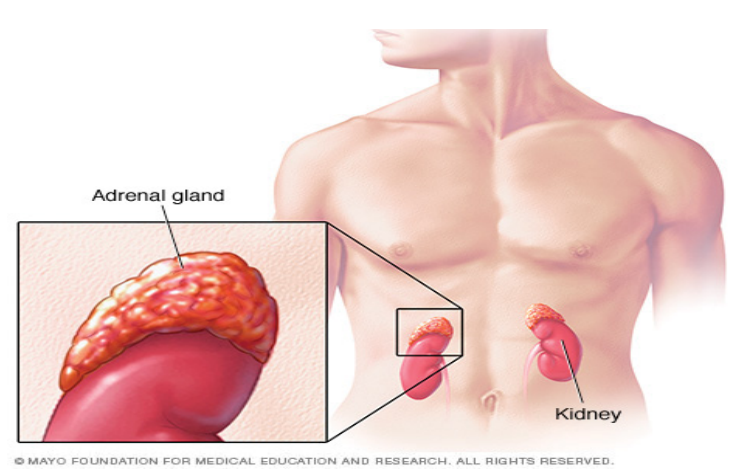

Figure 2: Adrenal gland.
$\mathrm{RL})$ and different processes were used like $\mathrm{O} / \mathrm{W}$ solvent evaporation methods and S/O/W evaporation methods [10-18].

\section{Material and Methods}

Microparticles were obtained by $\mathrm{O} / \mathrm{W}$ and S/O/W emulsionsolvent evaporation method. There batches were prepared during this study by using below steps:

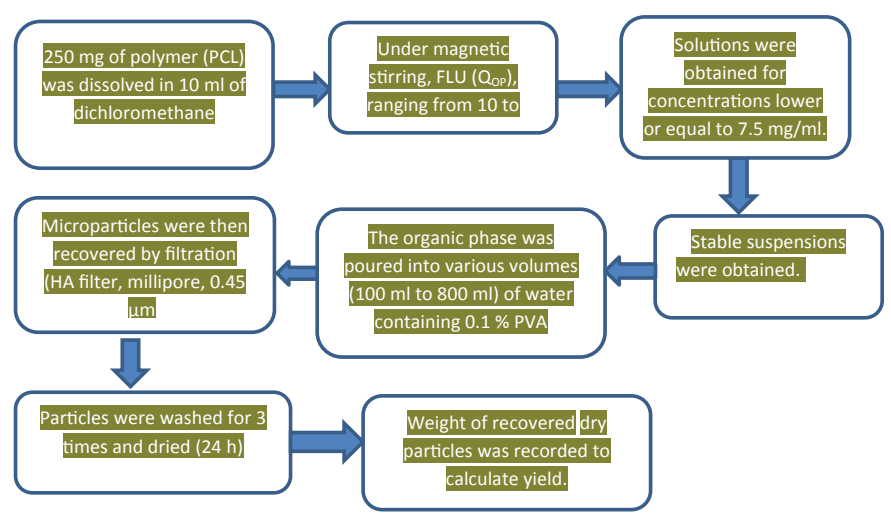

Preparation of microparticles

To obtain the Microparticles (MP), a modified O/W emulsionsolvent evaporation method was used [7]. In each case, $250 \mathrm{mg}$ of polymer (PCL, Eudragit RL, Eudragit RS or mixtures of these polymers) was dissolved in $10 \mathrm{ml}$ of dichloromethane and various amount of FLU (QOP) ranging from 10 to $150 \mathrm{mg}(1-15 \mathrm{mg} / \mathrm{ml})$ were added under magnetic stirring.

It is generally admitted that the release of dispersed drugs from polymers, needs an initial diffusion of the solvent, a dissolution step and a retrodiffusion of the solution. It is also often assumed that the rate-limiting step is the diffusion of the drug from the matrix. Several studies have demonstrated that the release of low molecular drugs such as progesterone or phenothiazines from PCL-based microparticles

\begin{tabular}{|c|c|c|c|c|c|c|c|}
\hline \multirow{2}{*}{ Parameter studied } & \multirow{2}{*}{ Formulation name } & \multirow{2}{*}{ Method } & \multicolumn{4}{|c|}{ Concentrations in $10 \mathrm{ml}$ of dichlorometane } & \multirow{2}{*}{$\begin{array}{l}\text { Aqueous } \\
\text { phase (ml) }\end{array}$} \\
\hline & & & Fludrocortisone (mg/ml) & PCL (mg/ml) & Eudragit ${ }^{\circledR} \mathrm{RS}(\mathrm{mg} / \mathrm{ml})$ & Eudragit ${ }^{\circledR} \mathrm{RL}(\mathrm{mg} / \mathrm{ml})$ & \\
\hline $\begin{array}{l}\text { Assay } 1: \text { Volume of } \\
\text { the aqueous phase }\end{array}$ & $\begin{array}{l}\mathrm{Flu}^{5}-\mathrm{PCL}^{25}-800 \\
\mathrm{Flu}^{5}-\mathrm{PCL}^{25}-600 \\
\mathrm{Flu}^{5}-\mathrm{PCL}^{25}-400 \\
\mathrm{Flu}^{5}-\mathrm{PCL}^{25}-200 \\
\mathrm{Flu}^{5}-\mathrm{PCL}^{25}-100\end{array}$ & $\begin{array}{l}\text { O/W } \\
\text { O/W } \\
\text { O/W } \\
\text { O/W } \\
\text { O/W }\end{array}$ & $\begin{array}{l}5 \\
5 \\
5 \\
5 \\
5\end{array}$ & $\begin{array}{l}25 \\
25 \\
25 \\
25 \\
25\end{array}$ & - & - & $\begin{array}{l}800 \\
600 \\
400 \\
200 \\
100\end{array}$ \\
\hline $\begin{array}{l}\text { Assay 2: } \\
\text { Concentration of } \\
\text { fludrocortisone }\end{array}$ & $\begin{array}{l}\text { Flu }^{1}-\mathrm{PCL}^{25}-800 \\
\mathrm{Flu}^{2}-\mathrm{PCL}^{25}-800 \\
\mathrm{Flu}^{5}-\mathrm{PCL}^{25}-800 \\
\text { Flu }^{7.5}-\mathrm{PCL}^{25}-800 \\
\text { Flu }^{10}-\mathrm{PCL}^{25}-800 \\
\text { Flu }^{15}-\mathrm{PCL}^{25}-800\end{array}$ & $\begin{array}{l}\text { O/W } \\
\text { O/W } \\
\text { O/W } \\
\text { O/W } \\
\text { S/O/W } \\
\text { S/O/W }\end{array}$ & $\begin{array}{c}1 \\
2 \\
5 \\
7.5 \\
10 \\
15\end{array}$ & $\begin{array}{l}25 \\
25 \\
25 \\
25 \\
25 \\
25\end{array}$ & - & - & $\begin{array}{l}800 \\
800 \\
800 \\
800 \\
800 \\
800\end{array}$ \\
\hline $\begin{array}{l}\text { Assay 3: } \\
\text { Concentration of } \\
\text { fludrocortisone }\end{array}$ & $\begin{array}{l}\mathrm{Flu}^{1}-\mathrm{RS}^{25}-800 \\
\mathrm{Flu}^{2}-\mathrm{RS}^{25}-800 \\
\mathrm{Flu}^{5}-\mathrm{RS}^{25}-800 \\
\mathrm{Flu}^{7.5}-\mathrm{RS}^{25}-800 \\
\mathrm{Flu}^{10}-\mathrm{RS}^{25}-800 \\
\mathrm{Flu}^{15}-\mathrm{RS}^{25}-800\end{array}$ & $\begin{array}{l}\text { O/W } \\
\text { O/W } \\
\text { O/W } \\
\text { O/W } \\
\text { S/O/W } \\
\text { S/O/W }\end{array}$ & $\begin{array}{c}1 \\
2 \\
5 \\
7.5 \\
10 \\
15\end{array}$ & - & $\begin{array}{l}25 \\
25 \\
25 \\
25 \\
25 \\
25\end{array}$ & - & $\begin{array}{l}800 \\
800 \\
800 \\
800 \\
800 \\
800\end{array}$ \\
\hline \multirow{6}{*}{ Assay 4: Polymer } & $\mathrm{Flu}^{7.5}-\mathrm{PCL}^{25}-800$ & $\mathrm{O} / \mathrm{W}$ & 7.5 & 25 & & - & 800 \\
\hline & Flu $^{7.5}-\mathrm{PCL}^{12.5} / \mathrm{RS}^{12.5}-800$ & $\mathrm{O} / \mathrm{W}$ & 7.5 & 12.5 & 12.5 & & 800 \\
\hline & Flu $^{7.5}-\mathrm{PCL}^{6.25} / \mathrm{RS}^{18.5}-800$ & $\mathrm{O} / \mathrm{W}$ & 7.5 & 6.25 & 18.75 & & 800 \\
\hline & $\mathrm{Flu}^{7.5}-\mathrm{RS}^{25}-800$ & $\mathrm{O} / \mathrm{W}$ & 7.5 & & 25 & & 800 \\
\hline & $\mathrm{Flu}^{7.5}-\mathrm{RS}^{18.5} / \mathrm{RL}^{6.25}-800$ & $\mathrm{O} / \mathrm{W}$ & 7.5 & & 18.75 & 6.25 & 800 \\
\hline & $\mathrm{Flu}^{7.5}-\mathrm{RS}^{12.5} / \mathrm{RL}^{12.5}-800$ & $\mathrm{O} / \mathrm{W}$ & 7.5 & & 12.5 & 12.5 & 800 \\
\hline
\end{tabular}

Table 1: Formulations of fludrocortisone micro particles. 
was rapid, as the dissolution rate of pure drug crystals or faster; this phenomenon being attributed to the molecular dispersion of the drugs in the polymer [7].

The release of solid drugs randomly dispersed in homogeneous matrices, described by Baker and Lonsdale is a very gradual process: The solid drug dissolves from the surface layer and when it becomes exhausted of drug the next layer begins to be depleted [3].

\section{Particle size analysis}

Optical microscopy was used to estimate the microparticle size distribution. About $5 \mathrm{mg}$ of particles were vortexed in $1 \mathrm{ml}$ of 0.1 $\%$ PVA. The sphericity of the MP was estimated by the roundness parameter where a value of unity corresponds to a perfect circle, which was given by:

The ferret diameter, which is a measure of an object size along a specified direction, was used during particle size analysis. The Feret diameter averaged over all directions $(\angle \mathrm{F}\rangle)$ is equal to the ratio of the object perimeter $(\mathrm{P})$ and pi, i.e., $<\mathrm{F}>=\mathrm{P} / \pi$. There is no such relation between $<\mathrm{F}>$ and $\mathrm{P}$ for a concave object.

\section{Release studies}

In order to investigate the release of FLU from microparticles, various batches were suspended in $100 \mathrm{ml}$ of phosphate buffer $(0.1 \mathrm{M}$, $\mathrm{pH} 7.40)$ preheated at $37^{\circ} \mathrm{C}$. The fludrocortisone microparticles were suspended at a concentration of $10 \mu \mathrm{g}$ of fludrocortisone per $\mathrm{ml}$ of medium, near "sink conditions" but taking account of the sensibility of the analytical method (Table 1).

\section{Results and Discussion}

The volume of aqueous phase and presence of crystals in the suspension was studies with different formulation of polymers. The volume of aqueous phase was taken from 100 to $800 \mathrm{ml}$. In some cases, presence of crystal was also found (Table 2).

The surface aspect, the size and the residual water were determined as described in the experimental section (mean \pm s.d.; $n=3$ ), ND: Not Determined.

The surface aspect, the size and the residual water were determined as described in the Experimental section (mean \pm s.d.; $n=3$ ) (Table 3). ${ }^{*} \mathrm{P}<0.02$ versus Flu1-PCL $25-800$ to Flu 7.5-PCL 25-800.

The in vitro release experiments performed with PCL-based and Eudragit-based microparticles release experiment (in vitro) was performed which 'showed that, from polymeric matrix, FLU was not able to release, hence release studies were prolonged up to $12 \mathrm{~h}$. For the O/W PCL microparticles (FLU1-PCL25-800, FLU2-PCL25-800, FLU5PCL25-800, FLU7.5-PCL25-800) the maximum release, estimated by $\mathrm{Q} \infty$, was higher $(\mathrm{P}<0.02)$ than for the correspondent $\mathrm{S} / \mathrm{O} / \mathrm{W}$ microparticles (FLU10-PCL25-800, FLU15-PCL25-800) and was not significantly different from this obtained with the free drug (Table 4).

Results are calculated according Equation 4-6. Q $\infty$ denotes the release percentage at infinite time and $\mathrm{T} 75 \%$ indicates the time to obtain $75 \%$.

Different mixture of poly( $\varepsilon$-caprolactone $)$ and of Eudragit were used. Mixtures of Eudragit to study the permeability characteristics of coating. It was found that PCL is more biodegradable and having good release profile (Figures 3-5) [19,20].

\section{Conclusion}

The objective of this study was to obtain slow release FLU loaded microparticles, having goof efficacy parameters. In this study, small PCL

\begin{tabular}{|c|c|c|c|c|c|}
\hline Formulation name & Volume of the aqueous phase & $\begin{array}{l}\text { Presence of crystals in the } \\
\text { suspension }\end{array}$ & Residual water ( $\mu \mathrm{g} / \mathrm{mg} \mathrm{MP}$ ) & Mean Feret Diameter $(\mu \mathrm{m})$ & Roundness \\
\hline $\mathrm{Flu}^{5}-\mathrm{PCL}^{25}-100$ & $100 \mathrm{ml}$ & + & ND & ND & ND \\
\hline $\mathrm{Flu}^{5}-\mathrm{PCL}^{25}-200$ & $200 \mathrm{ml}$ & + & ND & ND & ND \\
\hline $\mathrm{Flu}^{5}-\mathrm{PCL}^{25}-400$ & $400 \mathrm{ml}$ & + & ND & ND & ND \\
\hline $\mathrm{Flu}^{5}-\mathrm{PCL}^{25}-600$ & $600 \mathrm{ml}$ & - & $1.27 \pm 0.18$ & $45.12 \pm 22.80$ & $0.74 \pm 0.27$ \\
\hline $\mathrm{Flu}^{5}-\mathrm{PCL}^{25}-800$ & $800 \mathrm{ml}$ & - & $1.24 \pm 0.16$ & $47.21 \pm 27.20$ & $0.85 \pm 0.21$ \\
\hline
\end{tabular}

Table 2: Characteristics of each suspension (assay 1) as function of the volume of the aqueous phase.

\begin{tabular}{|c|c|c|c|c|c|}
\hline Formulation name & $Q_{O P}(\mu \mathrm{g} / \mathrm{mg}$ of polymer) & Presence of crystals on the MP surface & Residual water $(\mu \mathrm{g} / \mathrm{mg}$ MP) & Mean Feret Diameter $(\mu \mathrm{m})$ & Roundness \\
\hline Flu'-PCL ${ }^{25}-800$ & 40 & - & $1.21 \pm 0.15$ & $41.9 \pm 20.0$ & $0.81 \pm 0.21$ \\
\hline Flu $^{2}-\mathrm{PCL}^{25}-800$ & 80 & - & $1.20 \pm 0.12$ & $43.2 \pm 25.8$ & $0.82 \pm 0.21$ \\
\hline Flu ${ }^{5}-\mathrm{PCL}^{25}-800$ & 200 & - & $1.24 \pm 0.16$ & $34.0 \pm 17.6$ & $0.87 \pm 0.22$ \\
\hline $\mathrm{Flu}^{7.5}-\mathrm{PCL}^{25}-800$ & 300 & + & $1.37 \pm 0.10$ & $38.7 \pm 18.4$ & $0.81 \pm 0.21$ \\
\hline $\mathrm{Flu}^{10}-\mathrm{PCL}^{25}-800$ & 400 & +++ & $1.74 \pm 0.08$ * & $41.9 \pm 22.9$ & $0.82 \pm 0.21$ \\
\hline $\mathrm{Flu}^{15}-\mathrm{PCL}^{25}-800$ & 600 & +++ & $1.71 \pm 0.09$ * & $44.4 \pm 34.0$ & $0.83 \pm 0.25$ \\
\hline
\end{tabular}

(A)

\begin{tabular}{|c|c|c|c|c|c|}
\hline Formulation name & $Q_{O P}(\mu \mathrm{g} / \mathrm{mg}$ of polymer) & Presence of crystals on the MP surface & Residual water $(\mu \mathrm{g} / \mathrm{mg}$ MP) & Mean Feret Diameter $(\mu \mathrm{m})$ & Roundness \\
\hline Flu $^{1}-\mathrm{RS}^{25}-800$ & 40 & - & $1.30 \pm 0.11$ & $40.6 \pm 20.6$ & $0.81 \pm 0.20$ \\
\hline $\mathrm{Flu}^{2}-\mathrm{RS}^{25}-800$ & 80 & - & $1.25 \pm 0.06$ & $41.7 \pm 24.8$ & $0.82 \pm 0.20$ \\
\hline Flu $^{5}-R^{25}-800$ & 200 & - & $1.29 \pm 0.05$ & $32.2 \pm 11.9$ & $0.76 \pm 0.24$ \\
\hline $\mathrm{Flu}^{7.5}-\mathrm{RS}^{25}-800$ & 300 & - & $1.32 \pm 0.09$ & $33.7 \pm 12.5$ & $0.95 \pm 0.22$ \\
\hline $\mathrm{Flu}^{10}-\mathrm{RS}^{25}-800$ & 400 & +++ & $1.77 \pm 0.10$ * & $32.6 \pm 15.1$ & $0.78 \pm 0.23$ \\
\hline Flu $^{15}-$ RS $^{25}-800$ & 600 & +++ & $1.83 \pm 0.10$ * & $30.0 \pm 13.5$ & $0.85 \pm 0.23$ \\
\hline
\end{tabular}

(B)

Table 3: Characteristics of microparticles as function of the fludrocortisone concentrations in the aqueous phase (QOP) (assays 2 and 3). 


\begin{tabular}{|c|c|c|}
\hline \multicolumn{1}{|c|}{ Batch name } & $\mathbf{Q}_{\boldsymbol{\infty}}(\mathbf{\%})$ & $\mathbf{T}_{75 \%} \mathbf{( h )}$ \\
\hline Flu & 86.8 & 0.19 \\
\hline Flu $^{1}-\mathrm{PCL}^{25}-800$ & 70.1 & 0.41 \\
\hline $\mathrm{Flu}^{2}-\mathrm{PCL}^{25}-800$ & 75.1 & 0.28 \\
\hline $\mathrm{Flu}^{5}-\mathrm{PCL}^{25}-800$ & 76.9 & 0.30 \\
\hline $\mathrm{Flu}^{7.5}-\mathrm{PCL}^{25}-800$ & 82.5 & 4,00 \\
\hline Flu $^{10}-\mathrm{PCL}^{25}-800$ & 59.8 & 3.94 \\
\hline $\mathrm{Flu}^{15}-\mathrm{PCL}^{25}-800$ & 54.6 & 3.88 \\
\hline
\end{tabular}

(A)

\begin{tabular}{|c|c|c|}
\hline Batch name & $Q_{\infty}(\%)$ & $T_{75 \%}(h)$ \\
\hline Flu & 86.8 & 0.19 \\
\hline Flu'$^{1}-R^{25}-800$ & 22.3 & 0.22 \\
\hline $\mathrm{Flu}^{2}-\mathrm{RS}^{25}-800$ & 20.6 & 0.23 \\
\hline $\mathrm{Flu}^{5}-\mathrm{RS}^{25}-800$ & 20.4 & 0.55 \\
\hline $\mathrm{Flu}^{7.5}-\mathrm{RS}^{25}-800$ & 12.6 & 3.50 \\
\hline Flu $^{10}-\mathrm{RS}^{25}-800$ & 14.3 & 3.42 \\
\hline $\mathrm{Flu}^{15}-\mathrm{RS}^{25}-800$ & 14.9 & 3.30 \\
\hline
\end{tabular}

(B)

Table 4: Release parameters of FLU and FLU-loaded microparticles (assays 2 and 3).

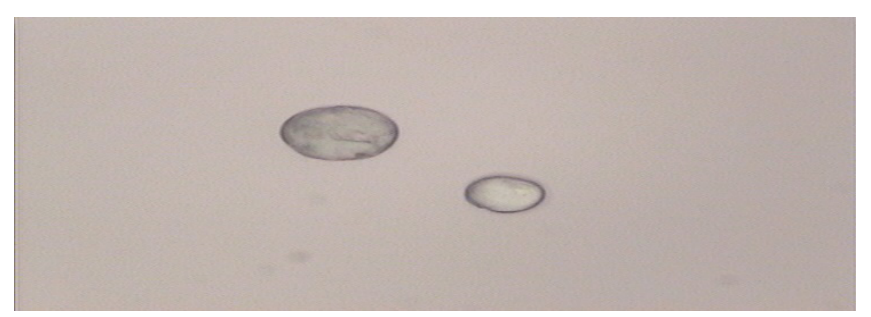

Figure 3: Microparticles-Suspensions obtained with (a) $200 \mathrm{ml}$ of aqueous phase (Flu5-PCL25-200), and (b) $800 \mathrm{ml}$ of aqueous phase (Flu5-PCL25-800).

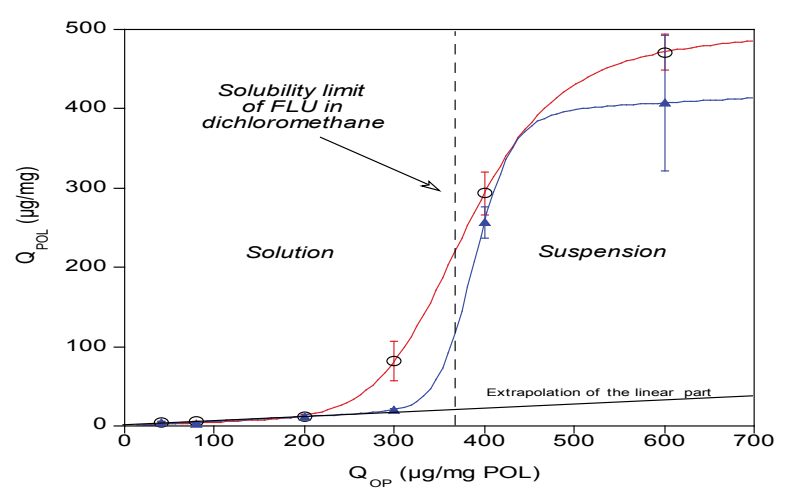

Figure 4: Incorporation profile of Fludrocortisone (FLU) into microparticles of poly ( $\varepsilon$-caprolactone) (assay 2: !) or Eudragit ${ }^{\circledR} \mathrm{RS}$ (assay 3: ") as function of the fludrocortisone concentration in the organic phase. QOP: Amount of FLU added in dichloromethane expressed in $\mathrm{\# g} / \mathrm{mg}$ of polymer; QPOL: Amount of FLU incorporated per $\mathrm{mg}$ of micro particles polymer. Each point represents the mean \pm S.D. of three separate determinations.

based microparticle of FLU was obtained when the O/W emulsionsolvent evaporation method was used with $7.5 \mathrm{mg} / \mathrm{ml}$ of FLU.

It was found that, the drug incorporation is directly link to its concentration. With low level of FLU, low level if drug drugs in microparticles were found, which is of no clinical use. However

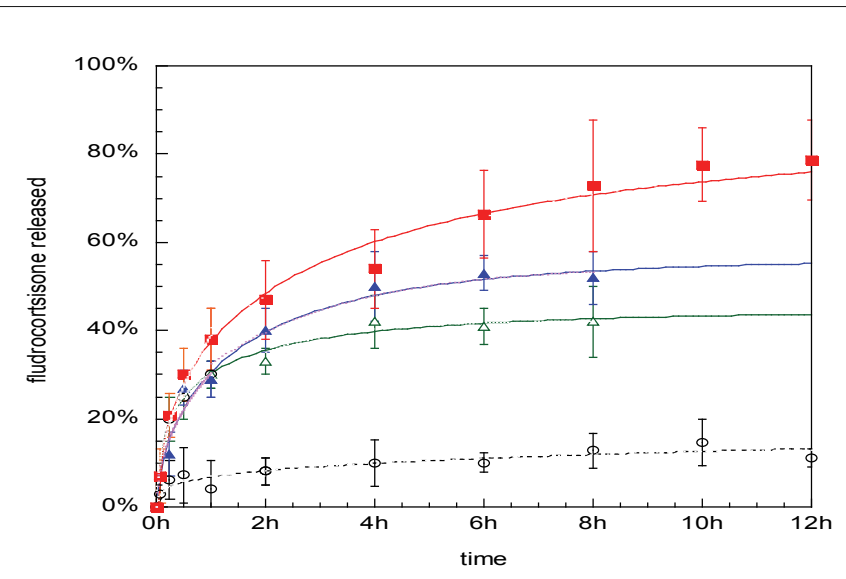

Figure 5: Release of fludrocortisone from microparticles in phosphate buffer $(0.1 \mathrm{M}, \mathrm{pH} 7.4,37 \circ \mathrm{C})$. Influence of the fludrocortisone concentrations (assays 2 and 3): (a) Poly ( $\varepsilon$-caprolactone) microparticles: Flu5-PCL25-800(\#) and Flu7.5-PCL25-800(\$), Flu15-PCL25-800 ("). (b) Eudragit ${ }^{\circledR}$ RS microparticles: Flu5-RS25-800 (\#) and Flu7.5-RS25-800 (\$), Flu15-RS25-800 ("). Each curve has been compared to free fludrocortisone (FLU: $\times$ ).

with saturated concentration, excellent release profile was obtained and sufficient quantity of FLU is found which is needed for the manufacturing purpose.

When saturated solution of FLU was used, it was leading to heterogeneous microparticles with several crystals embedded on the polymeric surface and it is found to be one of good alternative to achieve clinical goal. Poly( $\varepsilon$-caprolactone) (PCL) is found to be well tolerated by tissues without release of acidic metabolites unlike PLA/PLG. It is recommended for the development of sustained release formulation.

\section{References}

1. Gibaud S, Jabir A, Awwadi N, Ducki C, Astier A (2004) Poly( $\varepsilon$-caprolactone) and Eudragit ${ }^{\circledR}$ microparticles containing fludrocortisone acetate. Int J Pharm 269: 491-508.

2. Ali SA, Zhong SP, Doherty PJ, Williams DF (1993) Mechanisms of polymer degradation in implantable devices. I. Poly(caprolactone). Biomaterials 14 : 648-656.

3. Baker RW, Lonsdale HK (1974) Controlled release: Mechanism and rates. In Tanquary AC, Lacey RE (ed.) Controlled release of biologically active agents. Plenum Press, NY, USA, pp: 15-71.

4. https://www.dreamstime.com/stock-illustration-addison-s-disease-chronicadrenal-insufficiency-hypocortisolism-hypoadrenalism-signs-symptomsimage56508913

5. Benarroch EE (1997) Orthostatic hypotension: Diagnosis and treatment. Rev Neurol 25: 115-119.

6. Benoit MA, Baras B, Gillard J (1999) Preparation and characterization of protein-loaded poly(epsilon-caprolactone) microparticles for oral vaccine delivery. Int J Pharm 184: 73-84.

7. Chang RK, Price JC, Whitworth CW (1987) Enhancement of dissolution rate by incorporation into a water insoluble polymer, polycaprolactone. Drug Dev Ind Pharm 13: 249-256.

8. Donbrow M, Hoffman A, Benita S (1995) Gradation of microcapsule wal porosity by deposition of polymer mixtures (Eudragit RL and Eudragit RS). Phase separation of polymer mixtures and effects of external media and conditions on release. J Microencapsul 12: 273-285.

9. http://www.mayoclinic.org/diseases-conditions/addisons-disease/symptomscauses/dxc-20155757

10. Kuhnert-Brandstätter M, Gasser $P$ (1971) Solvates and polymorphic modifications of steroids hormones. II. Microchem J 16: 577-589. 
Citation: AL-Awwadi NA, Ali Hassan MM (2017) Challenges in Administration of Corticosteroids for the Treatment of Addison's Disease: A Case Study of Fludrocortisone Acetate. J Bioanal Biomed 9: 164-168. doi:10.4172/1948-593X.1000172

11. Kurganov BI, Lobanov AV, Borisov IA, Reshetilov AN (2001) Criterion for hill equation validity for description of biosensor calibration curves. Anal Chim Acta 427: 11-19.

12. Langenbucher $F$ (1972) Linearization of dissolution rate curves by the Weibull distribution. J Pharm Pharmacol 24: 979-981.

13. Lewis DA, Field WN, Hayes K, Alpar HO (1992) The use of albumin microspheres in the treatment of carrageenan-induced inflammation in the rat. J Pharm Pharmacol 44: 271-274.

14. Merke DP, Cutler GJ (1997) New approaches to the treatment of congenital adrenal hyperplasia. JAMA 277: 1073-1076.

15. Mesley RJ (1966) The infra-red spectra of steroids in the solid state Spectrochimia Acta 22: 889-917.
16. Salaman JR (1983) Steroids and modern immunosuppression. Br Med J 286 1373-1375.

17. Ponticelli C, De Vecchi AF, Tarantino A, Rivolta E, Egidi FM, et al. (1983) A search for optimizing corticosteroid administration to renal transplant patients. Kidney Int 23: S85-S89.

18. Provoost AP, de Keijzer MH, Kort WJ, Wolff ED (1982) Superiority of continuous infusion of prednisolone over daily injections in the prolongation of heart allograft survival in rats. Transplantation 34: 221-222.

19. Kehrl JH, Fauci AS (1983) The clinical use of glucocorticoids. Ann Allergy 50 2-8.

20. Haynes RC, Murad F (1980) Adrenocorticotropic hormone: Adrenocortical Steroids and their synthetic analogs; inhibitors of Adrenocortical steroid biosynthesis. In: Gilman AG, Goodman LS, Gilman A (eds.) Pharmacological Basis of Therapeutics. Mac-Millan Publishing Co, NY, USA, pp: 1466-1496. 